\title{
An Assessment of the Traditional Penal Code for Adultery and the Operations of Women's Rights Instruments Among the Igbos, in South-Eastern Nigeria
}

\author{
Okorie Albert, PhD, OSTAR Christopher, Chikwado Ezugworie* \\ Department of Political Science, University of Nigeria, Nsukka
}

*Corresponding Author: Chikwado Ezugworie, Department of Political Science, University of Nigeria, Nsukka

\begin{abstract}
The study evaluated the punishment system for adultery and the operation of women rights instrument in the traditional Igbo Society, in the South Eastern Nigeria. The study observed that penalties for adultery such as infliction of death or madness, denial of access to children, property and ejection from matrimonial homes and others undermined women's rights as enshrined in subsisting women rights instruments. The study employed survey and documentary methods based on logical deduction for data collection. Primary data was sourced from unstructured key informant interview. Contents analysis and transcript based methods were used in the analyses of data generated. Results of the investigation showed that most punishments for adultery in Igbo traditional society constitute a violation of women's rights, as stated in various international and domestic instruments on women's rights. We recommended that Nigerian Government should domesticate and include those instruments among her fundamental human rights, while civil society organisations should intensify campaigns against such obnoxious practices.
\end{abstract}

Keywords: Penal Code, Adultery, Women's Rights Instruments, Social Control, Marxist Feminist Theory

\section{INTRODUCTION}

The Igbos constitute one of the major tribes in Nigeria and occupy the present south-eastern states of Nigeria, namely: Abia, Anambra, Ebonyi, Enugu and Imo; in addition a large concentration of them are found in Delta and Rivers States. Naturally the Igbos are republican, because of the absence of centralized governmental system. Hence Afigbo (1973) describe the system as village republics, as opposed to the presidential monarchy practiced in few communities like Bini or Igala kingdoms that share boundaries with them. Notwithstanding the differences in nomenclatures across communities in Igbo land, the guiding philosophies and measures in social control and order are same.

In the traditional setting of an Igbo society, the village administration is the commonest organizational unit, made up of the oldest members of each family or lineage. The government at best could be described as gerontocracy, government by the council of the elders "Ndiichie or Ndiokenye" (Isieche I, 1976). Membership is also extended to titled men and traditional priests, hence they are also considered to be senior citizens given their social and spiritual relevance in the communities. The council of elders exercised all governmental powers: executive, legislative and judicial function, most times is regarded as autocratic arising from the republican and democratic inclination of the traditional Igbo society. Notwithstanding the council usually seek for the inputs of other interest groups such as the youths and women organizations prior to taking decisions on critical issues as a measure of inclusiveness in administration.

Prior to the advent of colonialism in Nigeria, the traditional Igbo society has sophisticated administrative system that served their social-economic and political purposes. In terms of social control, certain conducts were prohibited; those conducts that infringe on collectively accepted customs, norms and values (Busden, 1921 and Igbo, 2002). Adultery among married women, though a non-criminal offence is seen as a grievous sin and considered as a sacrilege among the Igbos. It is not just a sin before a man, but by extension to the immediate family, society and the Igbos. The gravity of the offence must have informed the spiritual dimension of the punishment among the Igbos. Secondly the sanctity of marriage as an institution and family life must have informed the 
development of local measures by Igbo communities to control adultery particularly among the women folk. These mechanisms manifest in various punishments and differ from one community to another notwithstanding few of those penalties have become widely accepted in many communities within the Igbo speaking states in Nigeria.

The interface between the Igbo speaking communities and European traders and missionaries, coupled with the advent of colonialism greatly distorted customary norms and practices that: knitted the Igbos together. As a result western legal framework with its components of rights and obligation displaced the traditional and customary norms and practices. The new legal system, particularly its position on human rights and obligations, to great extent tend to conflict with already existing traditional penal codes both for criminal and civic offences in the Igbo society. Notwithstanding that the traditional and English legal system are designed to achieve same purpose: social control and order; there exist differences on how the two sets of laws tend to achieve the stated goals. Moreover the end of colonialism and subsequent integration of states in Africa in international organizations such as United Nations, African Union etc, thus accelerated the universalization of western inspired human rights regime. This development informed the domestication and ratification by African States majority of human right instruments enacted by global and regional bodies. The implication of above is that human rights instruments are laws itself and its infringements are considered as crime against humanity, states and the global community.

Existing analyses on women's rights focused on socio-cultural practices against women across the globe and Africa in particular. Most of the analyses focused on the various mechanisms of ensuring social order in traditional African societies(Asomah 2015). Adingupu (2015);Otinche and Nnabuenyi (2015); Ottuh (2014);Omeiza and Ikponmwoba (2014); Nwala (1985) and Obaji (2009) amongst others evaluated various penalties for adultery among women of different communities in Igbo Society and other parts of Nigeria. However, the interface between penalties for adultery and operation of women's rights instruments in the Igbo Society of South- Eastern Nigeria is yet to attract systematic analyses. Thus, this study is aimed at examining traditional penal code for adultery and the operation of women's rights instruments in Igbo Society, South-Eastern Nigeria.

\section{MeTHOdOLOGY}

The study employed survey and documentary methods based on logical deduction for data collection. Primary data was sourced from unstructured key informant interview. For the purpose of the interview, a community was selected from each of the five Igbo speaking states and in each community, one paramount traditional ruler interviewed. Secondary data was sourced from publications/reports of global, regional and sub-regional organisations like the United Nations, African Union, the Federal Government of Nigeria, Civil Society Organizations, and Town / Community Development Unions. Transcript based method and content analysis based on logical inferences were adopted for data analysis. Table below shows distribution of the states, communities and respondents.

Table1. Distribution of States, Communities and Respondents

\begin{tabular}{|l|l|l|l|}
\hline & States & Communities & Key Informants \\
\hline 1 & Abia & Arohchukwu & Ekeoha Chekwas \\
\hline 2 & Anambra & Okija & Nwokoye Micheal \\
\hline 3 & Ebonyi & Okposi & Obajji Okwor \\
\hline 4 & Enugu & Enugu-Ezike & Simeon Osisi Itodo, \\
\hline 5 & Imo & Njaba & Chikwere Martins \\
\hline
\end{tabular}

\subsection{Traditional Penal Code For Adultery and the Operations of Women's Rights Instruments Among the Igbos: Theoretical Perspective}

This study appropriated the basic propositions of the Marxist Feminist theory as framework of analysis. Proponents of the theory include Clara Zetkin, Alexander Kollontai and Alison Jaggaramongst others. The Marxist Feminist theory is an offshoot of the works of Karl Marx and Frederick Engels in their analyses of how the historical changes in the social relations of production heralded social change at the different times in the history of the development of society. At a stage in the development of society, a new system of social relations of production, based on private ownership of property emerged. This system of production relations subsequently led to the 
emergence of a dominant class (the haves) and a vassal class (the haves not), with the former emerging powerful due to their ownership of the means of production and distribution. The ideas in Marxist Feminism were first developed in the work of Frederick Engels titled "The Origin of the Family, Private Property and the State". Engels work established the nexus between Marxism and Feminism. Deriving from the Marxist Perspective which sees the history of society as the history of class struggle, Marxist Feminists argue that the basis for inequality is embedded in the exploitative Capitalist system, which allows those who own the means of production and distribution (the haves or bourgeois) to exploit those who exchange their labour or knowledge for wages (the haves not or proletariats). In the case of women, the kind of labour they supplied was that which mainly nonproductive-basically domestic work was. Hence, they were paid nothing or were grossly underpaid.

Marxist- Feminists also argue that the emergence of private ownership of private property, as the basic factor determining the social relations of production also resulted in the historical overthrow of Matriarchy and the enthronement of Patriarchy. This enthronement of Patriarchy put men in a position of leadership, thereby, giving them the power to determine the laws governing society and family life. Mark and Engels et al (2004:67) noted that "the overthrow of mother right was the world historic defeat of the female sex. The man seized the reins in the house, also, the woman was degraded, enthralled, the slave of the man's lust, a mere instrument for breeding children". Engels further notes that the first effect of the sole rule of the men that was now established is shown in the patriarchal family. Consequently, the men, who are mostly the leaders in society and the heads of families, make decisions that lead to the exploitation of women.

Marxist-Feminists argue that exploitation, discrimination and domination of women would continue, until the system, which allows for men to dominate the class of those who own the means of production, using it to institutionalize exploitation of women through state policies, cultural practices others-Capitalism, is replaced with a system that grants equal access to material resources, devoid of patriarchal manipulations, perpetuated through state policies, religion and tradition, and prevents the accumulation of surplus value, through free labour or underpaid labour of the women folk, by a male exploitative class- Socialism.

The basic assumptions of the Marxist-Feminist theory can be summarized as follows:

1. That the exploitation of women and the inequality between men and women is a product of the historical change in the social relations of production, which brought about private ownership of property as against common ownership of property.

2. That the era of private ownership of property brought about a dichotomy in society, with the emergence of an upper class, which possessed resources such as land and capital, enabling them to control the means of production, thereby exploiting the labour of those who do not own capital and land- the lower class, in exchange for meagre wages.

3. That those who were able to acquire private property were mostly men. Hence, the emergence of the ownership of private property also led to the emergence and dominance of patriarchy.

4. That the patriarchal system resulted in the domination of women by men, and the institution of the man as the supreme head of the family, with women and children being subject to his rules and directives.

5. That the superiority of the man in the family led to further exploitation of the woman, as she was forced to exchange unpaid domestic labour for her upkeep, thereby, relieving the employer (the man), the liability of paying for that labour.

6. That this position of economic disadvantage which women find themselves makes them alienated from the process of decision making and formulation of rules guiding society and family, hence, subjecting them to conditions that coerce them to abide by laws and traditional norms which violates their rights.

7. That the solution to the exploitation of women in the society cannot be found within the liberal capitalist political system or order. Hence, any solutions to the plight of women must be targeted at not just advocating for the enactment of policies that favour women, or the abolition of cultural norms and traditions that denigrate women, but must advocate for the overthrow of the systems, practices and ideologies that limits the ability of women to access resources and acquire private 
property, which would grant them equal standing with men and equal say in the affairs that concern them. That equal access to resources and property, and commensurate benefits for labour expended would diffuse the notion of male superiority and allow for the perception of women as equal partners in the process of change and development.

By applying the above theoretical expositions, men historically are seen as superior to women in the household and in most traditional societies. This is because the men are perceived as being stronger, and hence, should be the providers of the material resources needed for the wellbeing of the family. As a result of this perception, property is passed down only through male children. As a consequence of this economic disadvantage, women are left at the mercy of the men and have little or no say in decision making processes that concerns them.

Mechanisms of crime control in traditional African societies including the Igbo society are designed to favour men over women. Some offences are perceived as more grievous when committed by women and negligible when committed by men. This is because, in traditional Igbo society, women are perceived to be either under the control of their fathers or brothers, or under the control of their husbands, in which case they are considered part of the property of their husband, since he paid their bride price.

Adultery is one offence which is considered to be a sacrilege when committed by women. It is seen not just as an offence against the man and his family, but an offence against the land and the gods. Lopsided punishments for adultery, skewed against women, exist in various communities across Igbo land. In Enugu-Ezike Community of Enugu state, a woman who commits adultery is humiliated and forced to confess publicly, and if she refuses, is inflicted with madness or struck with death through black magic, but a man who commits adultery goes free provided he doesn't commit the offence with a married woman. What is more disturbing is the fact that the definition of what constitutes adultery is quite blurred. In communities like that mentioned above, being seen in compromising positions or even having some form of body contact with a man, even when it is not of a romantic nature, might be equated with adultery. Since men are the leaders in society and heads of families, and owners of property, giving them an economic advantage over the women, they make the rules and ensure it does not affect them. Even when women wish to challenge such obnoxious practices, they fail because they lack the resources, and in some cases knowledge to stand up against such practices. Since they are already economically disadvantaged and in most cases dependent on men for their material wellbeing, they accept the punishments given to them or risk being thrown out of their homes empty handed.

Women's freedom from obnoxious cultural practices such as repugnant punishments for adultery can only be actualized when they rise up to challenge the patriarchal institutions that prevents them from acquiring resources needed to challenge this exploitative system. It is only when women have the intellectual and material resources possessed by their male counterparts that they can challenge patriarchy, the notion of male superiority and the institutions that limit their access to resources and wealth, which would empower them to influence and change cultural practices such as harsh and discriminatory punishments for adultery, which were instituted to keep them perpetually dominated.

\subsection{Punishment System for Adultery and Women Right Instruments}

In several communities around the world, evidences abound of cultural practices that are antithetical to the provisions of human rights laws and practices. In Africa, there still exist traditional practices and laws that constitute violations of human rights. Among the Igbo people of Nigeria, some of these cultural practices still persist. Adultery is one offence which is frowned at in different cultures and societies the world over, however, the punishment systems defer. In Africa, punishments for adultery appear to be one sided as the female culprits bear the bulk of the punishment while their male counterparts go free with minimal or in some cases no punishment at all. More so, some of the punishments prescribed for adultery are too severe and in some cases, repugnant to natural justice. Punishments for adultery in Igbo society include; restricting the access of women to their children, forcefully ejecting the woman from her matrimonial home, restricting/ denying the woman access to her property including those that are jointly acquired, and infliction of madness or death.

The elevation of human right practices above cultural and traditional practices and considerations tend to have made obsolete the traditional punishment system for civil and criminal offenses in Igbo land. Nigeria is a signatory to various international laws and instruments targeted at protecting the rights of 
women. Some of the instruments include; Convention on the Elimination of all Forms of Violence Against Women (CEDAW), adopted in 1979, Declaration on the Elimination of Violence Against Women, adopted by the UN General Assembly in 1993, Beijing Declaration and Platform for Action, adopted by the Fourth World Conference on Women in 1995,International Covenant on Civil and Political Rights (CCPR), and the International Covenant on Economic, Social and Cultural Rights (CESCR), both entered into force in 1976, Convention against Torture and other Cruel, Inhuman or Degrading Treatment or Punishment (CAT), entered into force in 1987, for the purpose of prohibiting torture and the African (Banjul) Charter on Human and Peoples' Rights, adopted in 1981, by the Organisation of African Unity (OAU), amongst others. Regardless of the forgoing, cultural practices that violate women's rights still continue to exist.

\subsection{Infliction of Madness or Death and the Right to Dignity and Life}

Adultery among married wives in Enugu-Ezike, a community in the present Enugu State, Nigeria attracts severe punishment, which ranges from infliction of madness to death. To demonstrate the seriousness of the offices Omeiza and Ikonmwoba (2014) noted that it is forbidden for married wives to conceal before her husband amorous advances towards her by men. It is also an abomination for a married woman to chat with a man while taking bath in the bathroom. According to them once a pride price of a lady is paid, her relationship with other men is highly restricted, even when she is yet to pack into her matrimonial home. In their custom a married woman from Enugu- Ezike or married to an Enugu -Ezike man, who engages in adultery, stands the risk of their ancestral fathers afflicting her with incurable sickness or madness, which many eventually led to death.

In addition, her husband and first son may suffer infirmities in a situation where they continue to eat meals prepared by the lady or interact in which ever manner,being aware she is having an affair with another man.A prominent traditional ruler in the town, Igwe Dr. Simeon Osisi Itodo of Esodo Aji, confirmed the assertion above. According to him:
If we caught an adulterous woman, she is expected
to perform. Certain ceremonies in order to appease
the land otherwise she will be afflicted with madness
or death (quoted in Omaizu and Ikonmwoba, 2014:1).

According to the traditional ruler, this culture was passed to them from their forefathers, and no one is exempted: indigenes, non-indigenes, Christians and non-Christians, once married to Enugu- Ezike man (Omaiza and Ikonwoba, 2014).

In Njabaa town in Imo state Nigeria, similar punishment awaits adulterous women. A case was narrated about Nkechi, a married woman who was kidnapped and unfortunately raped before she was released. Despite the shock and trauma of that experience, she was made to undergo the traditional cleansing process known as "Oriko"to undo the rape which tradition erroneously presumes an act of infidelity on the part of the woman. Failure to perform the traditional cleansing rituals might have led to the death of her husband. This custom is similar to that found in Enugu-Ezike. This custom reveals shortcomings that are prevalent in most African cultures- the fact that they are not a product of thorough objective thinking, and hence, they fail to take account of special cases. Nkechi was raped and should not have been made to go through the process of "Oriko"as if she was guilty of infidelity. Just like in Enugu-Ezike, the cleansing process is usually made public. Sometimes, a woman who does not confess is struck with madness and compelled by a force to name all the men she has had affairs with. It is believed that the act of infidelity by a woman opens the family to attacks. Businesses begin to crumble, jobs lost and hardship ensues.

Ogwashi-Uku in Delta State is another community where adultery is a grievous sin and considered as an abomination. In Ogwashi-Uku town if an adulterous woman is caught and her husband is still interested in the marriage, the woman will be compelled to visit the shrine of the village where her husband comes from accompanied by the women folk "Umu-Ada" for sacrifices and cleansing. Furthermore the women will force her to cook for the Umu-Ada and as well pay a fine to be determined by elders "Dimkpa", who also will receive the reports of what transpired in the shrine from Umu-Ada. However failure on the part of the adulterous woman to meet these conditions required in the cleansing process, the sin of adultery could led to her death or madness (Adingupu, 2015). 
Section IV of the 1999 Constitution of Nigeria enumerates the fundamental rights of Nigerians. Oneof such rights states:

Rights to dignity of human person (S.34):

Every person is entitled to the dignity of his/her person and no one shall be subjected to torture, inhuman or degrading treatment.

Article 3 of the Protocol to the African Charter on Human and People's on the Rights of Women in Africa states:

1. Every woman shall have the right to dignity, inherent in a human being and to the recognition and protection of human and legal rights.

2. Every woman shall have the right to respect as a person and to the free development of her personality.

To protect these rights, the protocol further provides that;

3. State parties shall adopt and implement appropriate measures to prohibit any exploitation or degradation of woman.

4. States parties shall adopt and implement appropriate measures to ensure the protection of every woman's right to respect for dignity and protection of women from all forms of violence, particularly sexual and verbal violence.

Also, the Universal Declaration of Human Rights provides that all individuals have the right not to be subjected to torture, or other cruel, inhuman or degrading treatment or punishment. Article 5 of the African (Banjul) Charter on Human and People's Rights states:

Every individual shall have the right to the respect of the dignity inherent in a human being and to the recognition of his legal status All forms of exploitation and degradation of man, particularly slavery, slave trade, torture, cruel, inhuman or degrading punishment and treatment shall be prohibited.

Considering that infidelity is a sensitive issue which affects all parties involved, it is important to maintain some kind of discreetness in the settlement/reconciliation process, to prevent further emotional or psychological harm. However, the nature of practices relating to adultery in the African setting does not allow for discreetness as it is not just a family affair, but a community affair. It exposes culprits to further ridicule, humiliation and stigmatization, even when they are genuinely repentant. It also affects the reconciliation process as the husband might find it difficult to forgive or live with the woman after such public embarrassment. The whole process does not in any way protect the dignity of all the parties involved.

Infliction of madness, death and all sorts of public humiliation on women who commit adultery contravenes their right to life and dignity of human person as clearly stipulated in the various provisions presented above. The humiliation which such women go through, such as being compelled to dance naked around the community, public confession and in some cases, public beating, is repugnant to natural justice and demeans their person and dignity. Table below shows recorded cases from selected communities of women inflicted with madness or death as a punishment for adultery in Igbo Society between 2000 to 2017.

Table2. Recorded Cases of Women Inflicted with Madness or Death as a Punishment for Adultery in Selected Igbo Communities between 2000-2017

\begin{tabular}{|l|l|l|c|}
\hline S/N & States & Communities & No of Victims \\
\hline 1. & Abia & Arohchukwu & 15 \\
\hline 2. & Anambra & Okija & 18 \\
\hline 3. & Ebonyi & Okposi & 25 \\
\hline 4. & Enugu & Enugu-Ezike & 20 \\
\hline 5. & Imo & Njaba & 23 \\
\hline
\end{tabular}

Source: Researchers Field Work (2019) 


\subsection{Ejection from Matrimonial Homes and Women's Right to Integrity and Security}

Ejection of women from their matrimonial homes due to adultery is a prevalent practice in Igbo Society. Offences like infidelity are usually made to be women offences in Igbo land, and even when the men are culprits, they receive little or no punishment, whereas, a woman faces divorce and is sent out empty handed. DLIFLC (2012) states that divorce in Igbo land does occur for a myriad of reasons such as; adultery, particularly when perpetrated by women. When divorce occurs, it is customary for the wife to leave her husband's home and return to live with her parents.

In Umuozu, a community in Nwangele LGA, Imo state, there was a case involving a mother of two who was stripped naked and conveyed in a wheel-barrow to her father's house for committing adultery. The young mother of two was married but her husband died shortly before the incident, and was yet to be buried. She was alleged to be a serial adulteress. The husband was an indigene of Eshiukwu in Nwangele LGA. She was stripped naked and put in a wheel-barrow with her two children amidst war songs which were chanted by the angry mob made up of youths, before she was finally returned to her father's compound in the nearby community of Isiala. It was alleged that the reason for her illicit actions was economic, as she needed money to feed her family. Her husband's death was blamed on her infidelity. According to the mob, her action was a taboo and is against the customs and traditions of the people. Eye witnesses disclosed that the woman was caught in the act, but the youths who took charge of sending her back to her father's house failed to reveal who her partner in the said crime was (Esezocor, 2014). This story captures the usual treatment given to women who are found guilty of adultery, not just in Igbo land or Nigeria, but also in most countries of Africa. Such actions are demeaning, and could lead to physical harm to the women concerned.

Without any intention of trivializing adultery, it must be stated that the manner in which women are treated as a result of this act is unfair. Since Adultery is considered shameful not just to the culprit but to her entire family, the researcher observes that a woman who is sent away from her matrimonial home usually finds herself abandoned not just by her husband and his family, but byher own family too. In effect, she is rendered destitute in most cases, and has to struggle to carter for herself, with little or no help from her family. Since she is considered the property of her husband, as a result of the bride price paid to her parents before the marriage, and in accordance with customary law, she is not allowed to leave with or get a share of properties which she jointly acquired with her husband. As a result of this, women who are victims are forced to start life from the scratch and are exposed to prostitution, sexual assault and even rape, in cases where they have nowhere to go. Such exposure threatens their right to integrity and security as it constitutes a threat to their life.

Article 3 of the Universal Declaration of Human Rights states that:

Everyone has a right to life, liberty and security of Person.

Article 4 of the African (Banjul) Charter on Human and People's Rights states:

Human beings are inviolable. Every human being shall be entitled to respect for his life and the integrity of his person. No one may be arbitrarily deprived of this right.

Also, Article 6 of the above charter states:

Every individual shall have the right to liberty and to the security of his person.

Article 4(1) of the Protocol to the African Charter on Human and Peoples' Rights on the Rights of Women in Africa puts this clearly states:

Every woman shall be entitled to respect for her life and integrity, security and protection of her person in the home, in her family, in society and throughout the country. No one shall thus have the right to beat a woman or commit acts that publicly shame or humiliate her.

From the provisions of the various international laws, conventions and charters, we can see that women's rights are infringed upon in the course of administering punishments for adultery. According to Odigie-Emmanuel (2010), the Protocol to the African Charter on Human and People's Rights on the Rights of Women in Africa was adopted on $11^{\text {th }}$ of July, 2003, and has been signed by 
the Nigerian Government, but sadly, the Government has been unable to ensure its full implementation. Odigie- Emmanuel quoted Richard Falk who said, "For various reasons associated with public opinion and prides, governments are quite ready to endorse (even formerly) standards of human rights, despite their unwillingness to uphold these standards in practice". Thus, ejecting a woman from her matrimonial home as penalty for adultery exposes her to danger and hence, contravenes her right to integrity and security.

Let us consider the story of a couple, both from Enugu Ezike who were both cheating. This resulted in the death of one of their sons and the other son became mentally imbalanced. As time proceeded, the woman began to have mental problems and it was said to be as a result of her infidelity. Realizing this, the husband ejected her irrespective of the fact that he was also a culprit. This reveals that women are highly marginalized and receive the consequences of any misconduct more than their male counterparts. Table below shows recorded cases of women who were ejected from their matrimonial homes as a punishment for adultery across selected communities in the South-Eastern Nigeria between 2000 to 2019 .

Table3. Case of Women Ejected from their Matrimonial Homes as a Punishment for Adultery in Selected Igbo Communities between 2000-2017

\begin{tabular}{|l|l|l|l|}
\hline S/N & States & Communities & No of Victims \\
\hline 1. & Abia & Arohchukwu & 18 \\
\hline 2. & Anambra & Okija & 14 \\
\hline 3. & Ebonyi & Okposi & 20 \\
\hline 4. & Enugu & Enugu-Ezike & 22 \\
\hline 5. & Imo & Njaba & 10 \\
\hline
\end{tabular}

Source: Researchers Field Work (2019)

\subsection{Denial of Access to Property in the Matrimonial Home And Women's Right of Inheritance}

Ordinarily, a woman under Igbo customary laws has no right of inheritance. She can only inherit property through her male children. When she is found guilty of adultery, and in most cases, consequently sent out of her matrimonial home, it further jeopardizes her chances of inheriting anything in her matrimonial home. Issues of inheritance come into play when the original owner of a property passes away. In line with that, Article 21 of the Protocol to the African Charter on Human and Peoples' Rights on the Rights of Women in Africa states:

A widow shall have the right to an equitable share in the inheritance of the property of her husband. A widow shall have the right to continue to live in the matrimonial house. In case of remarriage, she shall retain this right if the house belongs to her or she has inherited it.

We can deduce from the above that a woman who acquired property jointly with her husband, or who owns some properties while still in her husband's house, should not be barred from inheriting those properties as a result of adultery. Similarly, for a woman who was not divorced by her husband after she committed adultery, and continued living in her matrimonial home, she still retains her right of inheritance and cannot be disinherited by her husband's relatives. This should be the case especially in marriages where properties were acquired jointly. However, in reality, this is rarely obtainable.

Under customary law in Igbo Society, a woman doesn't have rights of inheritance. The properties she acquires in her matrimonial home are seen as belonging to the husband as she herself is seen as part of his property. A woman found guilty of adultery worsens her chances of inheritance and might only have access through the benevolence of her sons and relatives. Izunwa (2015) noted that settlement of property is in theory an available relief under customary divorce law regime; however in reality it does not exist. This is largely on account that in the southern part, particular among the Igbos, wives are strictly taken as among the possessions of their husbands. The implication is that whatever a woman may claim to have acquired in terms of property are in the strict sense, the husband's property by extension. Therefore under customary divorce, it is herculean to "lawfully" establish properties that belong to the woman. Notwithstanding most men in the exercise of equitable discretion permit divorced wives to go with such items like clothes and personnel effects they entered into the marriage with. Others may go far as allowing their divorced wives to leave with properties the received from 
relatives by way of settlement at the point of marriage. However the reality is that majority of the assets singly or jointly acquired are likely to be taken away from the woman except by the man's benevolence. In sum settlement of property under the customary law becomes discretionary relief to be granted.

Chikwere (2014), states that, when issues like a case of divorce arise due to infidelity; the woman suffers most because she would be deprived of all her property and also her children. Moreover this procedure constitutes permanent divorce and the action of the husband will be upheld by the native law. The wife, so treated is deprived of all her property and also her children; indeed, neither ever was hers. This is why mothers especially favour male children. They cannot inherit directly from their husbands. Rather, inheritance goes to male children and by extension, to the wives and mothers. This is also why the Strategic Objective A.1, 60 (f) of the Beijing Declaration states " action should be taken by governments to mobilize to protect women's rights to full and equal access to economic resources, including the right to inheritance and to ownership of land and other property, credit, natural resources and appropriate technologies". Hence Article 17 of the Universal Declaration of Human Rights states

1. Everyone has the right to own property alone as well as in association with others.

2. No one shall be arbitrarily deprived of his property".

Similarly Article 7 of the AU Protocol on the Rights of Women in Africa states that:

(c)In the case of separation, divorce or annulment of marriage, women and men shall have the right to an equitable sharing of the joint property deriving from the marriage.

Consider the story about a woman previously cited above from Imo State, who was found guilty of adultery and bundled out of her matrimonial home back to her father's house. In her own case, her actions were motivated by the need to survive. Moneys gotten from her illicit affairs were used to feed the family, including her husband. Some of the family properties might have been acquired using the money gotten from her affairs as well, considering the fact that the unholy behaviour lasted for some years. Having sent her back to her father's house, customarily, she is not allowed to inherit any property from her husband. Ab initio, none of his property was ever hers, as she herself is part of the properties. However, going by international laws and conventions, such actions would be wrong, as the woman in question must have contributed to the acquisition of the properties, and thus, has the right of inheritance. This is why Article 17 (2) of the Universal Declaration of Human Rights states; "no one shall be arbitrarily deprived of his property". Table below shows women who were denied access to property in their matrimonial homes as a punishment for adultery in the selected communities in Igbo Society between 2000 to 2019.

Table4. Cases of Women Denied Property in their Matrimonial Homes as a Punishment for Adultery in Selected Igbo Communities between 2000-2019

\begin{tabular}{|l|l|l|l|}
\hline S/N & States & Communities & No of Victims \\
\hline 1. & Abia & Arohchukwu & 10 \\
\hline 2. & Anambra & Okija & 21 \\
\hline 3. & Ebonyi & Okposi & 20 \\
\hline 4. & Enugu & Enugu-Ezike & 30 \\
\hline 5. & Imo & Njaba & 22 \\
\hline
\end{tabular}

Source: Researchers Field Work (2019)

\subsection{Restricting Women's Access to their Children and Rights of Separation, Divorce and Annulment of Marriage}

Restricting or denying a woman access to her children is one of the prominent punishments for adultery in Igbo traditional society. Nwokoye (2014) notes that in Igbo land, when issues like the case of divorce arises due to infidelity, the woman suffers most because she would be deprived of all her property and also her children. Basden (1921:17) states that: 
The procedure constitutes permanent divorce and the action of the husband will be upheld by the native law. The wife so treated is deprived of all her property and also her children; indeed, neither ever was hers. Her only possession are her cooking pots, market basket, and a few other small articles pertaining to domestic side of the house.

In certain Igbo communities, women who commit adultery are prevented from having contact with their children. As observed and through the interview granted by one of the respondents, Oyimaja, in Enugu-Ezike community of Enugu state, an adulterous woman who has children is forbidden from having contact with the first son. Her first son cannot eat her food as he is seen as the heir and hence, a representative of his father.

Onyemaechina (2005) noted that in Igbo traditional society, if a husband caught his wife stealing or caught her committing adultery, the wife is divorced and she refunds the bride price. There is to be a public hearing by the village elders before any major decisions are taken for a woman to leave her children and her husband. In most cases, husbands who have been cheated on, opt out of the marriage. Since in customary law, children are said to belong to the father, custody of the children is usually given to the men. A worrying issue also is the fact that most women are economically disadvantaged and hence, it becomes problematic to grant custody to them as the best interest of the child/children is considered paramount. Due to this material disadvantage and in some cases, as observed, low level of education and awareness, some men use their material advantage to prevent the women from having contact with their children.

The International Covenant on Civil and Political Rights guarantees among other rights, the rights to family life and children. Article 24 of the Convention grants the Rights for Children. Article 23 (4) states:

Parties to the present covenant shall take appropriate steps to ensure quality of rights and responsibilities of spouses as to marriage, during marriage and of its dissolution. In the case of dissolution, provision shall be made for the necessary protection of any children.

Going by article 23(4) of the International Convention on Civil and Political Rights, women should be allowed to have a relationship with their children even after a marriage has been dissolved, regardless of the cause of dissolution, provided the relationship is not harmful to the child. The principle of equality of rights and responsibilities of spouses provides that men and women should have the same rights over their children even in the event of a separation or divorce. However, this goes contrary to Igbo customs as children are said to belong to the father. When a mother commits adultery, she can be deprived of having a relationship with the children. This has been aptly captured by Basden (1921) when he states that a woman found guilty of infidelity in Igbo land can be divorced and deprived of all her property and her children.

Article 16 of Convention on the Elimination of All Forms of Discrimination against Women (CEDAW) clearly stipulates the measures to be taken to eliminate all discrimination against women in matters relating to marriage and family relations. However, practices across Igbo communities show that the provisions of the convention are not being adhered to. In Enugu Ezike community, it was observed that when a woman commits adultery, she is isolated. However, the men are allowed to freely have relationships with other women, provided they are not married. Regardless of whether or not a man is adulterous, his children are not at risk of illness or death. CEDAW provisions state that "in all cases, the interest of the children shall be paramount". Automatically separating a woman from her children on account of adultery after a divorce or separation is not always in the best interest of the child, especially when the children are below seven years old. It is important for young children to have a relationship with both of their parents. CEDAW is against any laws that exclusively awards ownership of a child to any of the spouses. This is why article 16, 1(d) states that parents shall have the same rights and responsibilities in matters relating to their children, regardless of their marital status. CCPR, A Protocol on the Right of Women in Africa and CEDAW are all in agreement against the unjust separation of parents from their children. 
Article 7 of the AU Protocol on the Rights of Women in Africa is concerned with the issues of separation, divorce, and annulment of marriage. Article 7 states:

a. parties shall ensure that women and men enjoy the same rights in case of separation, meaning the man and woman shall live in separate houses, or divorce, meaning the dissolution of the marriage, or annulment of marriage, meaning "not recognizing" the marriage. In this regard, the state parties shall ensure that:

In the case of separation, divorce or annulment of marriage, women and men shall have equal rights and duties towards each other and the children. In all cases, the interest of the children shall be paramount;

Based on CCPR, both men and women have a right to relate with their family and children. Regardless of the marital status of couples concerned, parents are to have access to their children, except in cases where it is determined that a parent concerned is harmful to the well-being of the child. CEDAW provisions states that all discrimination against women in matters relating to marriage and family should be eliminated. Article 16, 1 (d), states that both men and women would have the same rights and responsibilities during marriage and during dissolution. Hence, such practices like separation women from their children as seen in some Igbo communities as punishment for adultery contradicts the provisions of international conventions like CEDAW and CCPR.

Article 9 of the Convention on the Rights of the Child states;

1. States parties shall ensure that a child shall not be separated from his or her parents against their will except when competent authorities subject to judicial review determine, in accordance with applicable law and procedures, that such separations is necessary for the best interests of the child. Such determination may be necessary in a particular case, such as one involving abuse or neglect of the child by the parents, or one where the parents are living separately and a decision must be made as to the child's place of residence.

2. In any proceedings pursuant to paragraph 1 of the present article, all interested parties shall be given an opportunity to participate in the proceedings and make their views known.

Table five in the appendix shows women who have been denied access to their children as a punishment for adultery in Igbo Society between 2000 to 2019 .

Table5. Cases of Women Denied Access to their Children as a Punishment for Adultery in Selected Igbo Communities between 2000-2017

\begin{tabular}{|l|l|l|c|}
\hline S/N & States & Communities & No of Victims \\
\hline 1. & Abia & Arohchukwu & 18 \\
\hline 2. & Anambra & Okija & 14 \\
\hline 3. & Ebonyi & Okposi & 16 \\
\hline 4. & Enugu & Enugu-Ezike & 22 \\
\hline 5. & Imo & Njaba & 10 \\
\hline
\end{tabular}

Source: Researchers Field Work (2017)

\section{CONCLUSION}

Adultery is an immoral act frowned upon by various peoples, cultures and religions around the world. This is because of its potential to destroy human relationships and family units. Customary laws and conventions serve as mechanisms for social control and order. However certain penalties prescribed for adultery, especially in traditional African societies constitute themselves violations of human rights given subsisting women rights instruments. Considering the frailty of human nature and the tendency to make mistakes, there is bound to be instances where customary laws are broken. However situations where punishment for offences like adultery turns to physical or psychological violence, or 
dispossession, they are judged to be inconsistent with the law, as they violate the human rights of the individuals concerned. Beyond being punitive, customary laws should also aim at being correctional, and should operate within the bounds of both international and domestic laws. In view of the foregoing the study recommends domestication and elevation of international instruments to fundamental rights.

\section{REFERENCES}

[1] Adingupu, C. (2015). Ishi: The Pain of an Adulterous Woman in Ogwashi-Uku. Vanguard, May $22^{\text {nd }}$.

[2] Afigbo, A.E. (1973). The Indigenous Political Systems of the Igbo. Tarkh, 4(2), 13-20.

[3] African Union (2003). Protocol to the African Charter on Human and Peoples: Rights on the Rights of women in Africa. Addis Ababa: Aldus Press.

[4] Amnesty International, U.S.A, (2005). Women's Right: A fact sheet. http://www. amnestyusa.org/women (Retrievedon 17th May 2016)

[5] Asomah J.Y. (2015). Cultural Rights Versus Human Rights: A Critical Analysis of the Trokosi Practice in Ghana and the role of civil society. African Human Rights Law Journal.

[6] Basden, G. T (1921).Among the Igbos of Nigeria. Lagos: UPC.

[7] Basden, G.T. (2006). Among the Ibos of Nigeria. Gloucestershire: Nonsuch Publishing Limited.

[8] Besson S. \&Zysset A. (2012). Human Rights Theory and Human Rights History: A Tale of Two Odd Bedfellows. AncillaInris- International Law and Ethics.

[9] CAT (1984), Convention against Torture and Other Cruel, Inhuman or Degrading Treatment or Punishment: Adopted and opened for Signatures and Ratifications by the General Assembly Resolution $39 / 46$ of $10^{\text {th }}$ December.

[10] Chikwere, E.C (2014). Igbo Woman in Traditional Religious Setting. Journal of Modern European Languages, 3.

[11] COI Report (2013). Nigeria Country Origin Information Report.

[12] DLIFLC (2012). Igbo Cultural Orientation. http://www.google.com (Retrieved on $7^{\text {th }}$ May, 2016).

[13] Ejikeme, D.I. (2011). Igbo Jurisprudence: A Discourse on the Nature of Punishment in Traditional African Society. FilosofiaTheoretica, 1(1), 119-131.

[14] Eke, M. (2011). A town and its Unique culture: Commit Adultery and go Mad: Women of Enugu Ezike, be careful, News for you. http://www.google .com (Retrieved on $17^{\text {th }}$ May 2016).

[15] Ekwuru, G.E. (1999). The Pangs of an African Culture in Travail: The Ibo World in Disarray. Owerri: TotanPublishers Ltd.

[16] Esezobor J. L. (2014). Caught in the Act: Mother of Two Stripped, sent Packing in Imo State. Entertainment News and Life, January $18^{\text {th }}$.

[17] Igbo, E.U.M. (2007). Introduction to Criminology. Nsukka: University of Nigeria Press Limited.

[18] Isichei, E. (1976). A history of the Igbo People. London: The Macmillan Press Limited.

[19] Isichei, E. (1977). Igbo world: An Ontology of Oral History and Historical Description. London: Macmillan Education Limited.

[20] Izunwa, M.O (2015). A critique of certain aspects of the Grounds, Procedure and Beliefs attaching to Customary Divorce Law in Southern Nigeria. Journal of Law and Conflict Resolution, 7(5).

[21] Mark K. Engel, F. and Findlay, L.M (2004). The Communist Manifesto. Peterborough, ont: Broadview Press.

[22] Nwala, T. U. (1985). Igbo philosophy. Lagos: Literamed Publications.

[23] Nwokoye, M.A. (2014). Igbo women in Traditional Religious Setting. Journal of Modern Languages and Literatures, 3.

[24] Nzarga F.D. (2014). An analysis of Human Rights Violation by the Nigerian security services. Journal of Law, Policy and Globalization, 30.

[25] OAU (1982).African Banjul Charter on Human Rights.

[26] Obaji O. (2013). Okposi: Origin and Tradition. Ebonyi Online, June $20^{\text {th }}$.

[27] Odigie, E. O. (2010). Assessing Women's Rights in Nigeria. Pambazuka News, November $24^{\text {th }}, 2010$.

[28] Omeiza R. \&Ikponmwoba, O.S. (2014). Addressing Infidelity: The Enugu Ezike's Cultural perspective. The Nigerian Observer, October $10^{\text {th }}$.

[29] Otinche S.I. \&Nnabuenyi, U.M. (2015). Culture and the Right of the Rural Woman in Nigeria: An Overview. International Journal of Basic, Applied and Innovative Research, 4(2). 
An Assessment of the Traditional Penal Code for Adultery and the Operations of Women's Rights Instruments Among the Igbos, in South-Eastern Nigeria

[30] Ottuh, J.A. (2014). The Urhobo Traditional Justice System in Relation to Adultery in the Light of John 8:1-11: A Feminist Approach. Journals of Research in Humanities and Social Science, 2(3).

[31] Onyeamaechi U. (2005). Igbo Culture and Socialisation. http://www.google.com (Retrieved on July $20^{\text {th }}$, 2016).

[32] Uchendu, V.C. (1965). The Igbo of the South-Eastern Nigeria. New York: Rine Hart and Winton.

[33] United Nations (1976). "ICCPR and ICESCR" adopted by the UN General Assembly on $16^{\text {th }}$ December, 1966.

[34] United Nations (1981). "CEDAW", adopted and opened for Signatures and Ratification and Accession by the General Assembly Resolution 34/180 of $18^{\text {th }}$ December, 1979.

[35] United Nations (1995).Report of the International Conference on Population and Development, New York: United Nations Publications.

[36] United Nations (2014). Women's Rights as Human Rights. New York and Geneva: United Nations Publications.

[37] United Nations (2015).Universal Declaration of Human Hights. New York: UN Publications.

[38] United Nations (1995). Beijing Declaration and Platform for Action: UN Women.

\section{AUTHORS' BIOGRAPHY}

Okorie Albert, PhD, is a Senior Lecturer in the Department of Political Science, University of Nigeria, Nsukka, with a specialisation in comparative politics. His research interests cover politics of technology development, democratisation and party politics.

OSTAR Christopher, is a Lecturer in the Department of Political Science, University of Nigeria, Nsukka, with a specialisation in International Relations. His research interests cover politics of democratisation and electoral politics.

Chikwado Ezugworie, is a Lecturer in the Department of Political Science, University of Nigeria, Nsukka, with a specialisation in International Relations. His research interests cover politics of democratisation and electoral politics.

Citation: Okorie Albert, PhD, OSTAR Christopher, Chikwado Ezugworie. "An Assessment of the Traditional Penal Code for Adultery and the Operations of Women's Rights Instruments Among the Igbos, in South-Eastern Nigeria" International Journal of Political Science (IJPS), vol 6, no.4, 2020, pp. 33-45. doi: https://doi.org/10.20431/2454-9452.0604004.

Copyright: () 2020 Authors. This is an open-access article distributed under the terms of the Creative Commons Attribution License, which permits unrestricted use, distribution, and reproduction in any medium, provided the original author and source are credited. 